\title{
Maatilan riskien tunnistaminen ja jäsentäminen
}

\author{
Jarkko Leppälä ${ }^{1)}$ ja Risto Rautiainen ${ }^{2)}$ \\ ${ }^{1)}$ MTT Taloustutkimus, Vakolantie 55, 03400 Vihti jarkko.leppala@mtt.fi \\ ${ }^{2)}$ MTT taloustutkimus, Luutnantintie 13, 00410 Helsinki risto.rautiainen@mtt.fi
}

\section{Tiivistelmä}

Maatilan, kuten muunkin yrityksen johtamisessa keskeistä on hallita yrityksen riskejä. Maatalouden toimialalla yrittäjät tekevät itse suurelta osin sekä strategiseen päätöksentekoon että operatiiviseen taloudenhallintaan ja niiden tekniseen toteutukseen liittyvät tehtävät. He joutuvat tällöin myös tunnistamaan ja hallitsemaan näihin osa-alueisiin kuuluvia riskejä, mikä on monipuolista taitoa vaativa tehtävä toimialasta riippumatta. Muilla toimialoilla johtamistoimen hallintajärjestelmät ovat usein perustuneet hallinnon osaalueiden jakamiseen eri henkilöille. Maatiloilla yksi henkilö (tai perhe) vastaa usein kaikista osa-alueista. Johtamistoimen organisoinnin helpottamiseksi tarvittaisiin integroituja järjestelmiä, jotka helpottavat riskien tunnistamista ja korjaustoimenpiteiden jäsentämistä osa-alueittain.

Tässä MTT:n ’Huomisen maatila - tutkimusohjelmaan kuuluvassa hankkeessa tutkitaan ja kehitetään maatilojen johtamista ja riskienhallintaa. Hankkeen taustalla on vuosina 2005-2007 toteutettu Maatilojen turvallisuusjohtaminen - hanke (Maaturva- hanke), jossa MTT ja VTT kehittivät nk. Maatila- RH- välineet maatilojen riskienhallinnan avuksi. Riskien tunnistamiseen kehitettiin maatilan riskikartta, jonka suunnittelussa käytettiin hyväksi maatilayrityksille suunnattuja kyselytutkimuksia, asiantuntijatyöpajoja, ja case - tutkimuksia. Maatilan riskienhallintaa käsittelevistä tutkimuksista tehtiin systemaattinen haku joka rajattiin vuosina 1990 - 2008 julkaistuihin artikkeleihin.

Haku tuotti 555 artikkeliviitettä joista tarkasteluun valittiin 107 kriteerit täyttävää artikkelia. Nämä tutkimukset jaettiin maatilan riskien osa-alueisiin: henkilöiden terveys ja työturvallisuus - (28 viitettä), tuotanto ja tuotteet - (25 viitettä), talous - (22 viitettä), omaisuus - (18 viitettä) ja ympäristöriskit (18 viitettä). Artikkeleista saadut havainnot jäsenneltiin aihe alueittain riskilähteen tai riskiksi määritellyn kohteen mukaan. Usein artikkeleissa oli myös määritelty, miten kyseisiä riskejä voisi hallita. Toisinaan samassa tutkimuksessa käsiteltiin useampia maatilan toimintaan liittyviä riskejä ja niiden yhteyksiä. Yrittäjät joutuvatkin toiminnassaan kohtaamaan ja ottamaan huomioon useita riskejä ja riskitekijöitä samanaikaisesti. Tärkeimpiä tilan osa-alueita kartoittava kokonaisvaltainen riskienhallinta voi olla hyödyllinen työväline maatilojen johtamisessa, kun se tukee tilan toiminnan päämääriä ja tavoitteita. Riskienhallinta ja sen tutkimus on yhä monitieteisempää, mikä on tutkimukselle haasteellista mutta tuottaa samalla mahdollisuuksia löytää uusia keinoja torjua riskejä ja soveltaa tutkimusta käytäntöön. 


\section{Tausta}

Maatalous on monella tapaa riskialtis ala ja riskienhallintaan tarvitaan entistä tehokkaampia keinoja. Maatilojen suurimpia haasteita on ylläpitää kilpailukykyistä tuotanto- ja palvelutoimintaa muutosherkässä markkina- ja politiikkaympäristössä (Kay ym. 2008). Riskit koneketjuissa, kiinteistöissä tai eläinten hyvinvoinnissa voivat toteutuessaan aiheuttaa koko tilan toiminnan häiriintymisen tai jopa päättymisen. Tilan toimintaan liittyy myös riskejä jotka voivat aiheuttaa koko elintarvikeketjussa vakavia vahinkoja asiakkaille, koko alan kysynnälle sekä ympäristölle. (Lowe ym. 2008). Tämän kirjallisuustutkimuksen tavoitteena oli kartoittaa maatilojen turvallisuusriskejä ja riskienhallintaa koskevaa kirjallisuutta ja jäsentää havainnot riskien eri osa-alueisiin (kuva 1).

Artikkelissa jäsennettiin maatilojen riskienhallintaa koskevaa kirjallisuutta ja tutkimuksia MTT:n ja VTT:n kehittämän maatilan riskikartan mukaan (kuva 1). Riskikartan taustalla on VTT:n useilla toimialoilla käyttämä ja testaama PK-RH - riskityövälineen haavoittuvuuskartta. Maatilakohtaiset riskienhallinnan työvälineet ja riskikarttasovellus mallinnettiin MTT:n ja VTT:n Maatilojen turvallisuusjohtaminen (Maaturva) hankkeessa vuosina 2005-2007. Mallinnuksessa tuotettiin systemaattinen analyysi maatilan tärkeistä riskitekijöistä. (Leppälä ym. 2008; Hatch \& Cunliffe 2006). Riskikartassa riskit on jäsennetty sen mukaan, mihin tekijään riski kohdistuu. Nykyinen maatilan riskikartta (kuva 1) on tehty lähinnä viljantuotantoa, maidontuotantoa ja naudanlihan tuotantoa tarkastellen ja siitä voi myöhemmin muokata tuotantosuuntakohtaisia malleja. (Agronet 2008).

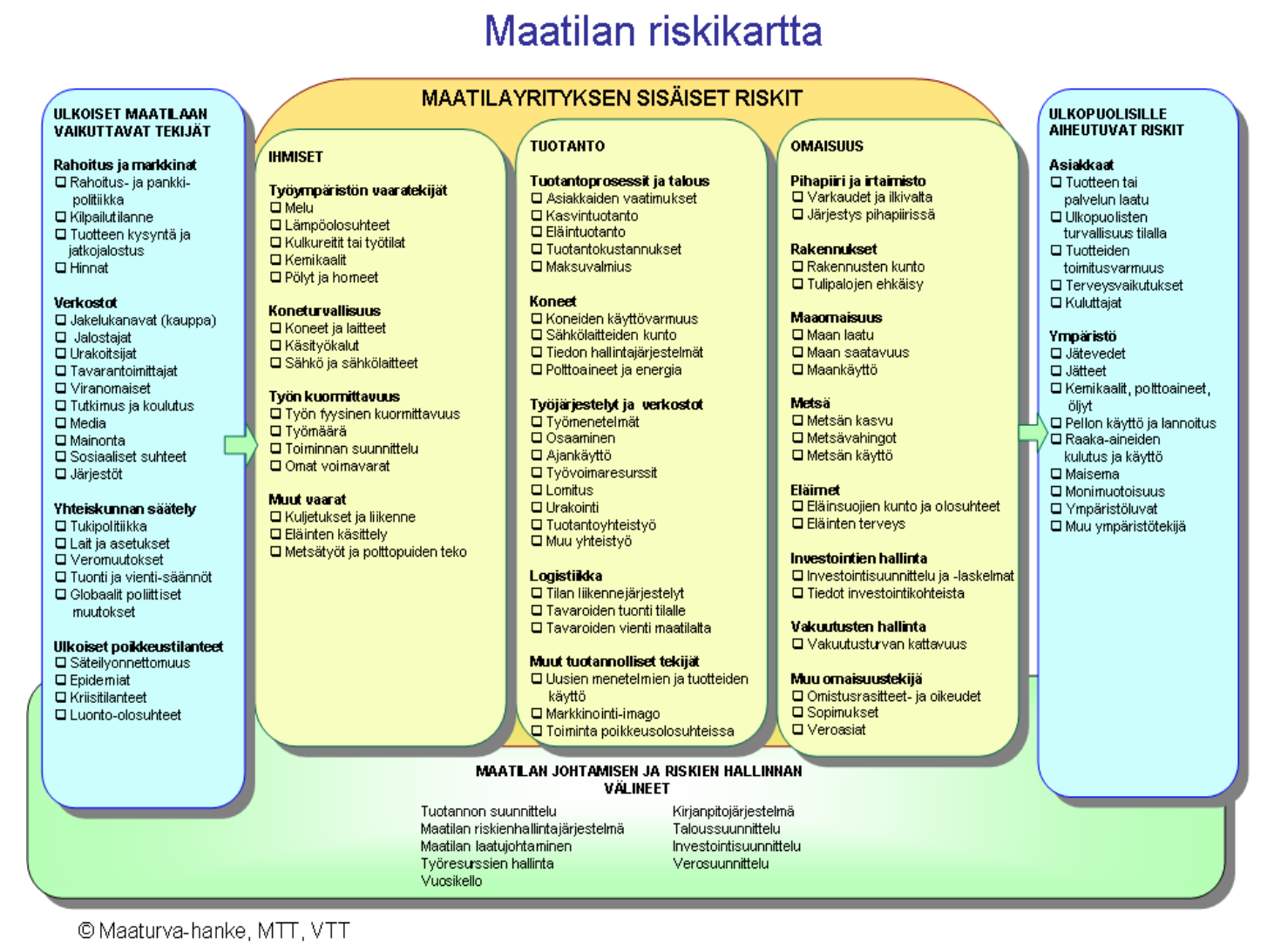

Kuva 1. MTT:n ja VTT:n kehittämä maatilan riskikartta .

Vakiintuneen määritelmänsä mukaan riski on määrätyn vaarallisen tapahtuman esiintymistaajuuden (tai - todennäköisyyden) ja seurauksen yhdistelmä. (SFS-IEC 60300-3-9). Riskienhallinnan toimintojen jäsentäminen ja seuranta helpottavat yritysten johtamista ja toimintaa (Eisenhardt 1985). Riskienhallinnan proseduurissa tunnistetaan vakavimmat riskit, arvioidaan riskien suuruus, suunnitellaan ja toteutetaan korjaavat toimenpiteet, seurataan uusien riskin ilmenemistä ja kehitetään yrityksen toimintaa. (COSO 2004; SFS OHSAS 18001). Riskienhallinnan tarve korostuu teknisesti toiminnallisella ja häiriöalttiilla alalla kuten maatalous. (Leppälä ym. 2008; Suutarinen 2004). Riskienhallinnasta on hyötyä vain, kun riskien tunnistamisen jälkeen kehitetään ratkaisuja havaittujen riskien hallintaan. (Leppälä ym. 2008; Jokipii ym. 
2005). Tutkimuksissa on käynyt selvästi ilmi että maatilayrittäjät tarvitsevatkin tilan johtamisen tueksi maatilatalouteen suunniteltuja systemaattisia välineitä, joiden avulla riskien tarkistaminen, suunnittelu, päätöksenteko ja toteutus ovat helposti erityyppisille tiloille räätälöitävissä. (Leppälä ym. 2008; Agronet 2008; Jokipii 2005). Eri toimialoilla kokonaisvaltaista riskienhallintaa on tarkasteltu kiinteänä osana yritystoimintaa. (Carnaghan 2006; COSO 2004; Kerko 2001). Maataloudessa kokonaisvaltaista johtamista riskienhallintaa käyttäen on tutkittu myös jonkin verran. (Leppälä ym. 2008; KSL 2007; Huirne ym. 2007).

\section{Kirjallisuustutkimus maatilojen riskienhallinnasta}

Kirjallisuushaku tehtiin pääasiassa kahden viime vuosikymmenen aikana julkaistuista artikkeleista. Tarkasteltavat tuotantosuunnat olivat samat kuin riskikarttaa tehtäessä eli viljan-, maidon- ja naudanlihan tuotanto. Muita tuotantosuuntia koskevia artikkeleja valittiin myös, jos artikkelissa oli samalla käsitelty maatiloja yleisemmin. Valituista artikkeleista tutkittiin riskikohde, riskienhallintaan liittyvä menetelmä, ja käytetty tai ehdotettu riskienhallintatapa. Lisäksi tutkittiin, miten eri riskit on tutkimuksissa määritelty ja jäsennetty riskien tunnistamista varten. .

Kirjallisuustutkimuksessa tehtiin haku Science Direct ja Cab Abstract - tiedonhakupalvelimien avulla tietyillä hakusanoilla. Haku tehtiin kahdessa vaiheessa englannin kielellä kansainvälisistä journalartikkeleista. Lisäksi tarkistettiin MTT:n tietokannan englanninkieliset kansainväliset artikkelit. Ensimmäisessä haussa kartoitettiin artikkelit hakusanoilla "farm risk management”. Tulokset käytiin otsikkotasolla läpi. Tämän jälkeen tehtiin vielä toinen haku tarkemmilla lisämääreillä. Lisämääreiksi valittiin maatilariskit, jotka kohdistuvat tilalla työtä tekevien ja oleskelevien ihmisten terveyteen, tuotantoon ja tuotteisiin, maatilan omaisuuteen, ympäristövaikutuksiin ja maatilan liiketoiminnan riskeihin. Käsitteiden valintaan vaikutti myös se, että hakutuloksen määrä oli käsiteltävissä ja yli sadan viitteen hakusanoilla pyrittiin tarkastelemaan vaihtoehtoisia hakusanoja. Hakua ei tehty kaikista teksteistä, vaan artikkeleiden otsikoista, abstrakteista ja avainsanoista. Valituissa tutkimuksissa ja kirjallisuudessa tuli lisäksi käsitellä erityisesti toiminnan ja työtehtävien riskien hallintaa sekä maatilan sisällä vaikuttavia toiminnan riskejä, joihin maatilan yrittäjä itse pystyy vaikuttamaan. Valittujen artikkeleiden lähdeviitteitä käytettiin täydentämään hakua.

\section{Haun tulokset}

Hakusanalla”farm risk management” löytyi keväällä 2009 Science Direct - ja Cab Abstract - haun avulla yhteensä 555 artikkeliviitettä. Huomioitavaa oli, että esimerkiksi Science Direct - hakupalvelimella julkaistujen "farm risk management" - tutkimusten määrä on kaksinkertaistunut 2000- luvulla. Löytyneitä artikkeleita jaoteltiin maatilan riskikartan riskikohteiden mukaan ja valittiin tarkasteluun kirjallisuuskatsauksen kriteerien mukaan. Useimmissa riskejä käsittelevissä artikkeleissa tutkimuksen kohteena oleva riski on aina suoraan mainittu artikkelin tiivistelmässä. Haun tuloksena valittiin esitetyillä kriteereillä tarkasteluun yhteensä 107 artikkelia ja kirjallisuusviitettä.

Riskien osa-alueet nimettiin artikkeleissa käsiteltyjen riskien määritelmien perusteella viiteen ryhmään. Näin ollen katsaukseen valitut artikkelit ja tutkimukset jaettiin maatilan henkilöiden terveys ja työturvallisuus - (28 viitettä), tuotannon ja tuotteiden - (25 viitettä), talouden - (22 viitettä), omaisuuden (18 viitettä) ja ympäristöriskien (18 viitettä) osa-alueisiin.

\section{Terveys ja työturvallisuus maatiloilla}

Maatilan henkilöiden terveyden ja työturvallisuuden osa-alueessa tarkastellaan maatilan sisäisten tapaturmien ja sairauksien riskejä. Katsauksen artikkeleista useimmat käsittelivät erityisesti viljelijöiden työturvallisuutta, mutta joukossa oli myös muun tilanväen terveyttä tai turvallisuutta koskevia aiheita kuten lasten turvallisuutta edistäviä tutkimuksia (taulukko 1). Maatiloilla on usein myös tilayrittäjäpariskunnan vanhempia, sukulaisia, työntekijöitä, urakoitsijoita ja vierailijoita, joiden turvallisuudesta tulee huolehtia (Angoules ym. 2007; Little 2005; Layde 1995).

Suurimmat tapaturmien lähteet maatalouden töissä ovat ihmisten työntekijöiden inhimilliset erehdykset, maatalouden koneet, traktorit, kotieläimet, käsityökalut, ja työskentelytasot. Muita tapaturmariskiä lisääviä tekijöitä ovat tekijöiden nuori tai vanha ikä, kiire, laaja karjakoko, pitkät työpäivät, väsymys, stressi, huonokuuloisuus, lääkkeiden käyttö, köyhyys, liukkaat ja heikot kulkuväylät, heikot sääolosuhteet, koneiden huono ylläpito ja aikaisempi vahinkoalttius (Rautiainen ym. 2009; Kaustell ym. 2007; Rautiainen ym. 2004; Sprince ym. 2003). Alkoholin käyttö työtehtävissä suurentaa tapaturmariskiä (Choi ym. 2005; Rautiainen ym. 2004; Stallones \& Xiang 2003). Stallonesin ja Beselerin (2004) mukaan 
maatalousyrittäjillä havaittiin masennusoireiden kasvua. Muuttuva tuotantoympäristö on myös tärkeä vahinkotekijä (Frank ym. 2004).

Henkilöiden vahinkoalttiudesta on vaihtelua, ja turvallisuusriskin osatekijänä voi olla huolimattomuus, tarpeeton riskinotto tai tapa toimia. Tällöin paremmalla asioiden johtamisella tai organisoinnilla voi ehkäistä ainakin osan maatilan vahingoista. Työkapasiteetista, työsuojelusta ja työergonomiasta huolehtiminen ehkäisisi myös monia vahinkoja ja ammattisairauksia (Suutarinen 2004), Yleisesti ottaen keinoja ehkäistä maatilojen terveys- ja turvallisuusriskejä ovat työturvallisuusriskien tunnistaminen ja ennakointi, tietoisuus seurauksista, sitoutuminen turvalliseen työkulttuuriin, riskien arviointi ja seuranta, ylirasittumisen välttäminen sekä yleinen tilan töiden kehittäminen. Turvallisia työtapoja edistetään mm. riskienhallintatoimenpiteiden koulutusten, turvallisuuskampanjoiden ja - tiedotuksen, säädösten, riskisimulointien, riski-indeksimittareiden, standardien ja vakuutusten avulla. (Rautiainen ym. 2009; Thurston \& Blundell-Gosselin 2005; Frank ym. 2004; Landsittel ym. 2001; Cole 1997; Hair 1991)

\section{Tuotannon ja talouden riskit}

Maatilan tuotteisiin ja tuotantoon kohdistuvat riskit aiheuttavat vahinkoa tilan tuotantokyvylle, tuotteiden laadulle, asiakkaille, sekä tilan ja alan imagolle ja jatkuvuudelle. Tyypillisesti tuotanto on riippuvainen tuotantokustannuksista ja tuotannon kannattavuudesta, tuotteiden laadusta ja turvallisuudesta kuluttajalle, mutta myös tilan sisäisten työketjujen teknisistä toiminnoista, sekä koneiden kunnosta ja yhteensopivuudesta (Collins \& Wall 2004; Just 2003; Lowenberg-DeBoer 1999; Loehman \& Nelson 1992; Hair 1991). Tuotanto on myös riippuvainen tilan liikennejärjestelyistä ja tuotteiden sekä raaka-aineiden kuljetuksista (Chamen ym. 2003). Tuotantoa koskevat artikkelit on tässä katsauksessa jäsennetty lähinnä tuotteiden laatuun ja toimitusvarmuuteen. Usein ne liittyvät samalla tilan taloudellisiin tavoitteisiin. Konerikot ja energiahuolto tuotantokoneiden käytössä ovat merkittäviä riskejä toimitusvarmuuden näkökulmasta tuotantosuunnasta ja toimialasta riippumatta (Carnaghan 2006; Chamen ym. 2003).

Kasvintuotannon tutkimuksissa tarkasteltiin kasvitauteja, tuhohyönteisiä, tuotannon määrään vaikuttavia olosuhdetekijöitä ja kasvintuotannon prosessien riskejä yleisesti. Tuotantoprosessien riskejä oli koetettu vähentää tai poistaa kasvipuolella mm. täsmäviljelyllä, reaaliaikaisella tuotantoinformaatiolla, kasvitautien, homeiden ja tuholaisten tunnistusohjelmilla, älykkäillä karttaohjelmilla, tuotevirtojen jäljitettävyysmenetelmillä, onnistumistekijöiden simulaatiolla ja kontrollimallien tai - mittareiden kehittämisellä (Binder 2007; Meinke 2001; D’Mello 1999; Lowenberg-DeBoer 1999).

Eläintuotannon riskienhallinnan tutkimuksissa käsiteltiin eläinten hyvinvoinnin riskejä, tuotteiden laaturiskejä, eläintautien torjuntakeinoja sekä tuotantoprosessien kontrolloinnin menetelmiä. Eläintautiriskiä lisäävät suuret karjakoot, huonot karjasuojan olosuhteet, eläinten hyvinvoinnin laiminlyönti ja rehun epäpuhtaudet. Eläintuotannon tutkimuksissa riskejä pyrittiin hallitsemaan mm. tautioireiden tunnistamisen, rehun taudinaiheuttajien ja riskitekijöiden seurantamittareiden avulla, hyvien viljelymenetelmien mallintamisen ja standardien kehittämisen, historiallisten tai kokemuksellisten kuvausten mallintamisen sekä erilaisten integroitujen järjestelmien, jalostustekniikoiden ja hyvinvointipisteiden seurantajärjestelmän kautta (Raizman 2006; Trevisi ym .2006; Collins \& Wall 2004; Noordhuizen \& Frankena 1999). Maatilayrittäjälle laajat eläintautiepidemiat, sekä pelko kemikaalien ja geeniteknologian vaikutuksista ovat myös imagoriski, joka voi vaikuttaa tuotteen kysyntään. (Roosen ym. 2005; Aumaitre ym .2002; Makki, 2001; Mepham \& Forbes, 1995).

Politiikka-, neuvonta- ja koulutusjärjestelmien toimintaa ja ohjausta ei pidä myöskään unohtaa tuotantotoiminnan riskienhallinnassa, jotta riskienhallinta olisi tehokasta vakavimpien riskien suhteen (Meinke 2001). Riskienhallinnan keinona voidaan pitää myös laadunhallintajärjestelmiä kuten HACCP johtamisjärjestelmää (Hazard analysis of Critical Control Points). Laadun- ja riskienhallinta ovat tavoitteiltaan samansuuntaisia. Yrittäjän mielikuva laadunhallinnan hankaluudesta voi estää laadunhallinnan järkevääkin toteutusta. Toisaalta voisi myös kehittää ketterämpiä ohjausjärjestelmiä. (Binder 2007; Romano ym. 2005; Taylor 2004; Noordhuizen \& Frankena 1999).

Maatilan taloutta ohjataan erilaisilla rahamääräisillä talousmittareilla. Talouteen liittyvät tutkimukset voisivat olla oma osa-alueensa mutta talousasiat maatilan sisäisissä toiminnoissa liittyivät tässä kuitenkin useimmiten tuotantoon ja sen kannattavuusriskeihin. Maatilayrittäjä voi käsitellä talouteen liittyviä riskejä omien tuotantojärjestelyjen ja investointien kautta tai pohtia strategisia tuotantoriskejä. Strategiset riskit liittyvät paljon tilan ulkopuolelta tuleviin hintariskeihin, politiikan reunaehtoihin ja niiden muutoksiin sekä kuluttajien kysynnän vaihteluihin tai arvoihin. (Just 2003; Fleisher 1991; Boehlje \& Trede 1977). Taloudelliset riskit yhdistyvät kaikkiin muihin riskien osa-alueisiin ja yritys voi mennä taloudelliseen 
konkurssiin tuotannon romahdettua, yrittäjän sairastuttua, tai tulipalon tai ympäristökriisin vuoksi. Erilaisilla taloudellisilla tunnusluvuilla voidaan mitata riskien taloudellista suuruutta ja vaikutuksia, mutta niillä ei selitetä kaikkia riskien syitä, tekijöitä ja seurausvaikutuksia. (Just 2003).

Aineiston taloutta käsittelevissä artikkeleissa maatilayrittäjän tuotantotaloudellisesti suurin riski on, että tila ei tuota riittävän hyvin kattamaan tuotantokustannukset ja tilan velanmaksut. Tutkimuksissa käsiteltiin, miten talouden riskienhallinta vaikuttaa maatilan sisällä tuotantojärjestelyissä. Tuotantokustannusten kasvu on uhka maatilan tuotannon jatkuvuudelle kannattavuuden ja tuotantokyvyn heikentymisen kautta, mikäli tila ei pysty sopeutumaan kasvaviin kustannuksiin tai ei voi lisätä kustannusten kasvua tuotteen hintaan. Tila voi myös yrittää kasvattaa muita tuloja tai parantaa tuottavuutta muilla järjestelyillä kuten pienentämällä tuotantokustannuksia tai ulkoistamalla kalliita ja työläitä työvaiheita. Tuotantotaloudellisten riskien torjuntakeinoja ovat mm. maatalouden tuet, tuotantoon ja tuotantovälineisiin liittyvät vahinkovakuutukset, tuotantopanosten- ja tuotteiden hintavaihteluihin varautuminen, herkkyystarkastelut, tuotantosopimukset, yrityksen ja tuotannon riskiportfoliot, jalostustoiminnan kestävä johtaminen, riskikontrollit ongelmatilanteisiin, tuotannon hajauttaminen, menestystekijöiden ja riskien stokastiset simulointimallit, maksuvalmiusturvat, lainsäädösten seurantamenetelmät, priorisointimenetelmät, kokonaisvaltainen tilanjohtaminen, yhteistyömenetelmät, verkostojohtaminen, pitkän aikavälin ennakointi, kestävä investointisuunnittelu sekä aina käyttökelpoinen tiedottaminen ja koulutus. (Lien ym. 2009; Hardaker 2006; Liu \& Pietola 2005; Ceyhan ym. 2003; Cloy \& Baker 2002; Meuwissen ym. 2001; Florey 2001; Meinke ym. 2001; Beal 1996; Bosch \& Johnson 1992; Turvey 1991).

\section{Maatilan omaisuusriskit}

Maatiloilla on useita arvokkaita kiinteitä kohteita kuten peltomaa, rakennukset ja metsä. Omaisuusriskit kohdistuvat maatilan omaisuuden arvon vähenemiseen tai pilaantumiseen. Tutkimuksissa tämän tyyppisiä riskejä ovat esimerkiksi kiinteistöjen tulipalot tai rakennusrikot, peltomaan laadun heikkeneminen, tulvat, ja eläin- tai luonnontuhot. Eläinsuojien ja rehuvarastojen heikot olosuhteet ovat myös tuotannollinen riski, mutta sen lisäksi eläinten huonovointisuus tai huonot olosuhteet heikentävät koko karjan arvoa. Useat eläinsuojien olosuhteita ja kuntoa kartoittavat tutkimukset liittyvät myös tuotantoon ja talouteen, mutta riski koko karjan tai tuotantostruktuurin menettämisestä on myös merkittävä omaisuusriski, jossa tuloksena on tilan investointikyvyn menetys ja konkurssi. (Schnier ym. 2002; Valle ym.1999; Trenter ym. 1993; Linnabary ym. 1991; Foran \& Staford-Smith 1990)

Keinoja torjua omaisuusriskejä ovat ehkäisevä riskien tunnistaminen kuten palo- ja pelastussuunnitelmien tekeminen. Bioturvallisuuden kontrollointi tilan kiinteistöissä voi estää tilalle tuhoisien eläintautiepidemioiden leviämisen. Säännöllinen tai kausittainen sisäilman mittaus voi tuottaa tietoa rakennusten kunnosta ja riskeistä (Teye 2008). Maatiloilla merkittäviä riskejä ovat kiinteistöjen tulipalot. Riskien lähteitä ovat heikkokuntoiset sähkölaitteet ja likaiset tai pölyiset pinnat, joita epäkuntoiset sähkölaitteet kuumentavat. Unohtaa ei pidä polttoaine - ja muiden paloherkkien materiaalien käsittelyä. Huollot ja huolellisuus ovat tärkeitä näissäkin. (Burnett \& Pritchard 1993; Shutske ym. 1991). Säännölliset tilatarkastukset, rakennusten kunnossapito, lämpötilan ja kosteuden seuranta sisätiloissa, tiedonhallinta tai palolaitoksen tarkastukset ehkäisevät omaisuusriskejä. Muita keinoja torjua riskejä löytyi tutkimuksista mm. parantaa eläinten hyvinvointia, hyvät tavat toimia ja työrutiinit, ulosteiden seuranta, uudet laidunnuksen organisointimenetelmät, karjakirjanpito ja vakuuttaminen. Luonnontuhojen (mm. villieläimet, myrskytuhot, tulvat) kohdalla riskien pienentämisen keinoja ovat vakuuttaminen ja riskin kohteen ja seurausten vaikutusmekanismien tutkiminen ja torjunnan kehittäminen. (White ym. 2008; Lundborg ym. 2005; Roper ym. 2003; Pivot ym. 2002; Foran \& Stafford-Smith 1990) Alueellisista onnettomuus- ja kriisitilanteiden käsittelystä ja toiminnoista löytyi ainoastaan Linnabaryn ym. (1991) tutkimus hätätilannetoiminnasta kemiallisten tai radioaktiivisten ainepäästöjen tapauksessa ja luonnontuhotilanteissa. Omaisuusriskeihin muilla toimialoilla liittyy myös rikosriskit, mutta niistä ei löytynyt tutkimuksia maatalousalaa koskien tässä aineistossa. Suomessa tätä on tutkittu vähän.

\section{Ympäristöriskejä koskevat aiheet}

Ympäristöriskien kohteena tutkimuksissa oli maatilan tekijät, jotka aiheuttavat ympäristövahinkoja maatilan välittömässä luonnonympäristössä tai alueellisesti. Maatilan ympäristövaikutukset vaikuttavat usein maatilan ulkopuolella ja ovat luonteeltaan ns. hajapäästöjä. Ympäristöriskit heikentävät luonnon ekosysteemien laatua ja ovat siten yhteydessä maatilojen tuotantokykyyn tai pelto-omaisuuden arvoon. Täten ympäristöriskit vaikuttavat sekä ulkopuolelta tilalle että tilalta ulkopuolelle. 
Tutkimuksissa keskeiset käsitellyt ympäristöaiheet olivat maan, ilman tai veden saastuminen, torjuntaainekemikaalien myrkyllisyys, maataloudesta tulevat jätteet ja jätevedet, luonnonvarojen käyttö, taudinaiheuttajat ja lannoitteista aiheutuva vesistöjen rehevöityminen sekä luonnon monimuotoisuuden heikentyminen. Pintavesistöjen ja pohjavesien riskienhallintaa tulee tarkastella erikseen (Reichenberger ym. 2007). Pyrkimyksenä katsauksen tutkimuksessa oli lähinnä tunnistaa ja mitata ympäristövaikutusten laajuutta ja seurausten vakavuutta sekä kustannuksia. Ilmaston muutosta tarkasteltiin maatiloihin liittyen lähinnä tuotantovaikutusten kuin ympäristövaikutusten näkökulmasta. Ympäristöriskien hallinnan keinoja tutkimuksissa oli ehdotettu mm. uusia tiedonkeruujärjestelmiä (state-space modelling), hyväksyttävien ympäristön laatuindikaattoreiden ja mittausjärjestelmien kehittämistä, torjunta-aine- ja jätevesipäästömittauksia ja integroituja päästö- tai panosmallinnuksia, HACCP- johtamisjärjestelmän tai muiden ympäristöjohtamisjärjestelmien soveltamista, ekologista riskipisteytysindeksiä, GIS- ohjelmien ympäristöriskisovelluksia, päästölähteiden johtamismenetelmiä, materiaalivirtamallinnuksia, politiikkajärjestelmien uudelleenorganisointia, ympäristöriskien vakuutusjärjestelmiä ja lopuksi taas neuvontaa ja koulutusta. (Goss \& Richards 2008; de Vos ym. 2006; Mishra ym. 2005; Sinden 2004; Wendroth ym. 2003; Bouma 2002; Sparling ym. 2001; McLay ym. 2001; Wagner 1999; Lang ym. 1995; Zalom 1993).

\section{Kokonaisvaltainen riskienhallinta}

Yleisen systeemiteorian mukaan yritysten ja organisaatioiden kokonaisuus on enemmän kuin osiensa summa. Tämä pätee myös maatilayrityksissä. Muutamissa kirjallisuusaineiston artikkeleissa tarkasteltiinkin useampia riskejä kokonaisvaltaisemmin eli holistisesti. Tähän ilmiöön liittyy se, kun maatiloilla kohdataan useita eri riskejä samanaikaisesti työtehtäviä ja tilakokonaisuutta johdettaessa. Tämä kompleksisuus vaikuttaa heti tilanjohtamisen ja toiminnan tasapainoon. (Florey 2001; Pannel ym. 2000; Wagner 1999). Jos keskitytään liikaa vaikka tuotantoriskeihin, niin työturvallisuusriskit voivat lisääntyä ja päinvastoin. Maatiloilla voidaan tarkastella ja kehittää riskienhallintaa kokonaisvaltaisesti maatilayrittäjien kohtaama tuotantoympäristö huomioiden. Tämän merkitys korostuu, jos esimerkiksi ilmasto-olosuhteet muuttuvat (Strand 2000). Jotkut turvallisuusriskit voivat vaikuttaa toteutuessaan myös muilla riskien osa-alueilla. Toisaalta jos muutamiin tärkeimpiin riskeihin on varauduttu paremmin, niin varautuminen niissä voi suojella koko tilan kaatumista onnettomuuden sattuessa. Riskienhallinta ei saa kuitenkaan olla itsetarkoitus, vaan se aina palvelee johtamista. Kokonaisvaltaisen tilanjohtamisen kehitys on riippuvainen olemassa olevista maatilojen riskimalleista, toimenpiteiden priorisoinnista ja aikatauluista, riskitietojen saatavuudesta ja tietojen käsittelystä, kustannuksista tai hyödyistä ja muutosten tarpeista ja vaikutuksista (Pannel ym. 2000).

\section{Johtopäätökset}

Kirjallisuuskatsauksessa etsittiin kirjallisuutta maatilojen riskienhallintaa koskevista artikkelijulkaisuista ja tutkimuksista. Kirjallisuushaun tulokset jäsennettiin maatiloille suunnitellun riskikartan mukaan. Tässä jäsennys kohdistettiin lähinnä maatilan sisällä vaikuttaviin tuotanto ja tuotteet -, terveys ja työturvallisuus -, omaisuus - ja ympäristöriskien osa-alueisiin. Maatilojen taloudellisia riskejä tarkasteltiin tässä katsauksessa osana tuotantoriskejä, mutta ne yhdistetään usein myös muihin osa-alueisiin. Tässä mielessä taloudellisten riskien tarkastelutapa on yksi kokonaisvaltaisen johtamisen keino. On kuitenkin huomattava, etteivät taloudelliset tunnusluvut selitä kaikkia tilan toiminnan riskejä, mutta yleensä kyllä indikoivat niitä lopulta.

Riskienhallintaa koskevasta kirjallisuudesta analysoitiin riskien kohteita, syytekijöitä, seurauksia ja hallintakeinoja. Tutkimuksissa tulisi riskien tunnistamisen ja yleisyyden toteamisen lisäksi tarkastella enemmän keinoja torjua riskejä ja niiden syitä. Riskienhallinnassa tarvitaan välillä tietoa syiden ja seurausten tarkoista yksityiskohdista ja riskien vakavuudesta sekä välillä tietoa riskienhallinnan koko proseduurista tunnistamisesta toimenpiteisiin ja seurantaan tai koko ruokaketjun toimintaan vaikuttavista riskeistä. Riskienhallinnan tutkimuksissa on tärkeää määritellä tarkastelun taso ja riskien kohde. Voidaan määrittää, hallitaanko merkittävimpiä riskejä esimerkiksi tilan kiinteistössä, työtehtävässä, työketjussa, koko maatilalla vai koko ruokaketjussa.

Turvallisuusriskien torjuntaan voi suunnitella ”puskureita” vähentämään vahinkojen vaikutusta. Päätöksenteossa ja toiminnassa voi huomioida useita eri riskejä ja miettiä niiden hallintaa. Valmiita malleja ja tarkastuslistoja käyttäen riskien tunnistamiseen ja torjunnan suunnitteluun menee vähemmän aikaa. Jos estetään yksikin vakava vahinko, on käytetty aika maksanut itsensä takaisin moninkertaisesti. Integroivia kokonaisvaltaisia riskienhallinnan menetelmiä on käsitelty maataloudessa vähän. Maatila- RH- välineet ja 
maatilan riskikartta (kuva 1) on yksi tapa tarkastella tilaa kokonaisvaltaisesti (Agronet 2008; Leppälä 2008). Periaatteena on, että muutaman henkilön pientiloilla johtaminen järjestetään kevyeksi toteuttaa, mutta varmistetaan samalla riittävä informaatio tilan toiminnasta. Jos tila ja tuotanto kasvavat, pohditaan lisää panosten lisäämistä toiminnan organisointiin ja johtamiseen. Riskienhallinnan avulla voidaan saada tietoa tilan toimintakunnosta ja edesauttaa tilan pitkän tähtäyksen tavoitteiden toteutumista. Riskienhallinnan tutkimusten monitieteisyys on kasvamassa, mikä lisää tutkimuksen haasteita mutta myös mahdollisuuksia.

\section{Lähteet}

Agronet. 2008. Maatilan riskien hallinta. Agronetin verkkosivu 31.1.2008. Saatavissa internetistä: https://portal.mtt.fi/portal/page/portal/AGRONET/Tilan_johtaminen/09.

Angoules, A.G., Lindner, T., Vrentzos, G., Papakostidis, C. and Giannoudis, P.V. (2007) Prevalence and current concepts of management of farmyard injuries. Injury, International Journal of the case of the injury 385. 526-533.

Aumaitre, A., Aulrich, K., Chesson, A., Flachowsky, G. \& Piva, G. 2002. New feeds from genetically modified plants. Livestock Production Science 74. ss. 223-238.

Beal, D.J. 1996. Emerging Issues in Risk Management in Farm Firms. Review of Marketing and Agricultiral Economics. 64 (3).

Binder, E.M. (2007) Managing the risk of mycotoxins in modern feed production. Animal Feed Science and Technology 133. 149-166.

Boehlje, M.D., Trede, L. (1977) Risk Management in Agriculture. Journal of the American Society of Farm Managers and Rural Appraisers. Vol. 41, No. 1.ss. 20-29.

Bosch, D. \& Johnson, C. 1992. An Evaluation of Risk Management Startegies for Dairy Cows. Southern Journal of Agricultural Economics. December 1992. ss. 173-189.

Bouma, J. 2002. Land quality indicators of sustainable land management across scales. Agriculture, Ecosystems and Environment 88. ss. 129-136.

Buitendijk, J. (1985) Effect of workability index, degree of mechanization and degree of certainty on the yield of sugar beet. Soil and Tillage Research 5. 247-257.

Burnett, G.A. and Pritchard, D.N. (1993) Electricity on the farm: safety and the law. Farm building progress 114. 12-14. Carnaghan C (2006) Business process modelling approach in the context of process level audit risk assessment: An analysis and comparison Periodical International Journal of Accounting Information Systems 7 170-204.

Ceyhan V., Bozoglu M., Cinemre H. A. (2003) Measuring yield and price risks for dairy farms and designing risk management strategies: the case of Tonya, Turkey. Bodenkultur 54 (4) 215-220.

Chamen, T., Alakukku, L., Pires, S., Sommer, C., Spoor, G., Tijink, F. and Weisskopf, P. (2003) Prevention strategies for field traffic-induced subsoil compaction: a review: Part 2. Equipment and field practices. Soil and Tillage Research 73 (1-2) 161-174.

Choi SW, Peek-Asa C, Sprince NL, Rautiainen RH, Donham KJ, Flamme GA, Whitten PS, Zwerling C. Hearing loss as a risk factor for agricultural injuries. Am J Ind Med 48(4):293-301, Oct. 2005.

Cloy, B. \& Baker, T. 2002. The Importance of Financial Leverage and Risk Aversion in Risk-Management Strategy Selection. Amer. J.Agr. Econ. 84(4). ss. 1130-1143.

Cole, H., Kidd, P., Isaacs, S., Parshall, M. \& Scharf, T. 1997. Difficult ecisions: A Simulation That Illustrates Cost Effectiveness of Farm Safety Behaviors. Agricultural Health and Safety: Recent Advances. ss. 117-124.

COSO (2004) Enterprise risk management - Integrated framework. Executive summary Committee of sponsoring Organizations of the Treadway Commission.

Goss, M. \& Richards, C. 2008. Development of a risk-based index for source water protection planning, which supports the reduction of pathogens from agricultural activity entering water resources. Journal of Environmental Management 87. ss. 623-632.

de Vos, J.A., Van Bakel, P.J.T., Hoving, I.E. and Conjin, J.G.(2006) Waterpas-model:A predictive tool for water management, agriculture and environment.Agricultural water management 86. 187-195.

D’Mello, J., Placinta, C. \& MacDonald, A. Fusarium Mycotoxins: a review of global implications for animal health, welfare and productivity. Animal Feed Science and Technology 80. ss.183-205.

Eisenhardt, K. 1985. Control: Organizational and Economic Approaches. Management Science, Vol 31, 2. ss. $134-149$. Fleisher, B. (1990) Agricultural risk management Lynne Rienner Publishers. Boulder. London.

Florey, B.H.W. (2001) The Increasing need for risk management strategies. Journal of the royal agricultural society of England 162.17-25.

Foran, B. \& Stafford-Smith, D. 1990. A Comparison of Development Options on a Northern Australian Beef Property. Agricultural Systems 34. ss. 77-102.

Frank, A.L., McKnight, R., Kirkhorn, S.R. and Gunderson, P. (2004) Issues of agricultural safety and health. Annual review of Public Health 25. 225-245.

Hair, D.M. 1991. Farm safety: problems and opportunities. Professional safety 36(11) 17-22.

Hardaker, J.B. 2006. Farm risk management: past, present and prospects. Journal of farm management 12 (10) $593-612$. 
Hatch, M.J. \& Cunliffe, A.L. 2006. Organization Theory: Modern, Symbolic, and Postmodern Perspectives. Oxford University Press. $400 \mathrm{~s}$.

Huirne, R.B.M., Meuwissen.M.P.M. and Van Asseldonk, M.A.P.M. 2007. Importance of whole-farm risk management in agriculture. In: Weintraub, A., Romero, C., Bjorndal, T. and Epstein, R. (2007) Handbook of Operations Research in Natural Resources. Springer. USA.

Jokipii, P, Teräväinen, H. \& Helin, J. 2005. Maatilan riskienhallinta. Tieto Tuottamaan 110. Pro Agria/MTT. 92 s.

Just, R. (2003) Risk Research in agricultural economics: opportunities and challenges for the next twenty-five years. Agricultural Systems 75. 123-159.

Kaustell KO, Mattila TEA and Rautiainen RH. 2007. Safety performance of animal confinement floors - slip, trip and fall injuries in Finland. Journal of Agricultural Safety and Health 13(4) 395-406.

Kay, R.D., Edwards, W.M. and Duffy, P.A. (2008) Farm management. McGraw-Hill International Edition. Sixth edition. 468p.

Kerko, P. 2001. Turvallisuusjohtaminen. Aavaranta-sarja no. 49. Oitmäki: PS-Kustannus. 368 s.

KSL. 2007. Kvalitetsystem i landbruket. KSL-standard. Norja: Matmerk. Saatavissa internetissä: http://kslmatmerk.no/seksjoner/ksl.

Landsittel, D., Murphy, D., Kiernan, N.E., Hard, D. \& Kassab, C. 2001. Evaluation of the Effectiveness of Educational Interventions in The Pennsylvania Central Region Farm Safety Pilot Project. Am.J. Ind.Med. 40. ss. 145-152.

Lang, R., Müller, A. \& Lenz, R. 1995. The Agroecological Information System within the Research Network on Agroecosystems Munich. Ecological Engineering 4. ss. 173-180.

Layde, P.M., Nordstrom, D.L., Stueland, D., Brand, L. and Olson, K.A. 1995. Machine-Related Occupational Injuries in Farm Residents. AEP 5 (6). 419-426.

Leppälä, J., Murtonen, M. Suokannas, A., Lehto,M., Sinisalo, A. \& Suutarinen, J. 2008. Maatilan turvallisuuden johtaminen - riskien tunnistamisen ja arviointivälineiden kehittäminen. MTT Research serie no. 126. MTT Agrifood Research Finland. Vihti. Finland. 110 p.

Lien,G., Hardaker J.B., van Asseldonk, M.P.A.M. \& Richardson J.W. 2009. Risk programming and sparse data: how to get more reliable results. Agricultural Systems, Volume 101, Issues 1-2, ss. 42-48.

Linnabary, R., New, J., Hall, R. \& Usrey, E. 1991. Attitudinal survey of Tennessee beef producers regarding evacuation during an emergency. JAVMA 199 (8).

Little, D.C., Vermillion, J.M., Dikis, E.J., Little, R.J., Custer, M.D. and Cooney, D.R. 2003. Journal of Pediatric Surgery 38: 5. 804-807.

Liu, X. and Pietola, K. 2005. Forward hedging under price and production risk of wheat. Agricultural. Agricultural and Food Science 14 (2) 123-133.

Loehman, E. \& Nelson, C. 1992. Optimal Risk Management, Risk Aversion and Production Function Properties.

Journal of Agricultural Resource Economics,17 (2). ss. 219-231.

Lowenberg-DeBoer, J. 1999. Risk Management Potential of Precision Technologies. Journal of Agricultuiral and Applied Economics, 31 (2). ss. 275-285.

Lowe P., Phillipson J. \& Lee R. 2008. Socio-technical innovation for sustainable food chains: roles for social science.

Trends in Food Science \& Technology 5:19.5. ss. 226-233.

Lundborg, G.K., Svensson, E.C. and Oltenacu P.A. 2005. Herd-level risk factors for infectious diseases in Swedish dairy calves aged 0-90 days. Preventive Veterinary Medicine 68 (2-4)123-143.

Makki, S., Somwaru, A. \& Harwood, J. 2001. Biotechnology in Agriculture: Implications for Farm-Level Risk Management. Journal of Agribusiness 19 (1). ss.51-67.

McLay, C., Dragten, Sparling, G. \& Selvarajah, N. 2001. Predicting groundwater nitrate concentration in a region of mixed agricultural land use. Environmental Pollution 115. ss. 191-204.

Meinke, H., Baethgen, W., Carberry, P., Donatelli, M., Hammer, G., Selvaraju, R. \& Stöckle, C. 2001. Increasing profits and reducing risks in crop production using participatory systems simulation approaches. Agricultural Systems 70. ss. 493-513.

Mepham, T. \& Forbes, J. 1995. Ethical aspects of the use of immunomodultion in farm animals. Livestock Production Science 42. ss. 265-272.

Meuwissen, M.P.M., Huirne, R.B.M.\& Hardaker, J.B. (2001) Risk and risk management: an empirical analysis of dutch livestock farmers. Livestock Production Science 69. 43-53.

Mishra, A., R.W. Nimon \& El-Osta, H.S. 2005. Is moral hazard good for the environment? Revenue insurance and chemical input use. Journal of Environmemtal Management 74. ss. 11-20.

Noordhuizen, J. \& Frankena, K. 1999. Epidemiology and quality assurance: applications at farm level. Preventive Veterinary Medicine 39. ss.93-110.

OHSAS 18001. 2000. Occupational health and safety management systems. Spesifications. Finnish Standards Association SFS. Helsinki.

Pannell, D.J. et al. 2000. Are we risking too much? Perspectives on risk in farm modelling. Agricultural Economics 23. 69-78. 
Pivot, J-M., Josien, E. \& Martin, P. 2002. Farms adaptation to changes in flood risk: a management approachs. Journal of Hydrology 267. ss. 12-25.

Raizman, E., Wells, S., Godden, S., Fetrow, J., Friendshuh, K. \& Oakes, J. 2006. Characterization of Minnesota dairy herds participating in a Johne's disease control program and evaluation of the program risk assessment tool. Preventive Veterinary Medicine 75. ss.22-33.

Rautiainen L, Ledolter J, Ohsfeldt R, Donham K, Zwerling C. 2009. Risk factors for serious injury in Finnish agriculture. Am J Ind Med.

Rautiainen, R., Lange, J., Hodne, C., Schneiders, S. \& Donham, K. 2004. Injuries in the Iowa certified safe farm study. Journal of Agricultural Safety and Health of ASAE. 10 (1).

Reichenberger, S., Bach, M., Skitschak, A. \& Frede, H-G. 2007. Mitigation strategies to reduce pesticide inputs into ground- and surface water and their effectiveness; A review. Science of Total Environment 384. ss. 1-35.

Romano, D., Cavicchi, A., Rocchi, B. and Stefani, G.2005. Acta Agriculturae Scand Section C 52-59.

Roosen, J., Thiele, S. and Hansen, K. (2005) Acta Agriculturae Scand Section C (2). 13-26.

Roper, T., Garnett, B. \& Delahay, G. Visits to Farm Buildings and Cattle Troughs by Bangers: a Potential Route for Transmission of Bovine Tuberculosis Between Badgers and Cattle. BCVA vol 11 (1).

Schnier, C., Hielm, S. \& Saloniemi, H. 2002. Comparison of the disease incidences of dairy cows kept in cold and warm loose-housing systems. Preventive Veterinary Medicin 53. ss. 247-261.

Shutske, J.M., Chaplin, J. and Jacobson, L.D. 1991. Applications of computer-based fire models in agricultural safety. Paper - American Society of Agricultural Engineers 91-5502.

SFS-IEC 60300-3-9. 2000. Dependability management. Part 3: Application guide. Section 9: Risk analysis and technological systems.

Sinden, J. 2004. Estimating the opportunity costs of biodiversity protection in the Brigalow Belt, New South Wales. Journal of Environmental Management 70. ss. 351-362.

Sparling, D., Lee, J. \& Howard, W. 2001. Murgo Farms Inc.: HACCP, ISO 9000 and ISO 14000. International Food and Agribusiness Management Review 4. ss. 67-79.

Sprince, N.L., Zwerling, C., Lynch, C.F., Whitten, P.S., Thu, K.,Logsden-Sackett, N., Burmeister, L.F., Sandler, D.P., Alavanja, C.R. 2003. Risk Factors for Agricultural Injury: A Case-Control Analysis of Iowa Farmers in Agricultural Health Study. Journal of Agricultural Safety and Health 9(1). 5-18.

Stallones, L.\& Beseler, C.2004.Safety Practices and Depression among Farm Residents.Ann Epidemiol 14. ss. 571-578. Stallones, L. \& Xiang, H. 2003. Alcohol Consumption Patterns and Work-Related Injuries Among Colorado Farm Residents. American Journal of Preventive Medicine 25 (1). ss. 25-30.

Strand, J.F. 2000. Some agrometeorological aspects of pest and disease management for the $21^{\text {st }}$ century. Agricultural and Forest Meteorology 103. ss.73-82.

Suutarinen, J. 2004. Management as a risk factor for farm injuries. Journal of agricultural safety and health 10(1) 39-50. Taylor,E.2004. Perceptions of "the bureaucratic nightmare" of HACCP:a case study. British food journal. 106(1) 65-72. Thurston, W. \& Blundell-Gosselin, H.J. 2005. The farm as a setting for Health promotion. Health \& Place 11. ss. 31-43. Tranter, W., Morris, R., Dohoo, I. \& Williamson, N. 1993. A case-control study of lameness in dairy cows. Preventive veterinary medicin 15. ss. 191-203.

Trevisi, E., Bionaz, M., Piccioli-Cappelli, F. and Bertoni, G. 2006. The management of intensive dairy farms can be improved for better welfare and milk yield. Livestock Science 103. 231-236.

Turvey, C. 1991. Regional and farm level risk analyses with the single-index model. Northeastern journal of agricultural and resource economics. 20 (2). ss. 181-188.

Wagner, W.C. 1999. Sustainable Agriculture: how to sustain a production system in a changing environment. International Journal for Parasitology 29. 1-5.

Valle, P., Martin, S., Tremblay, R. \& Bateman, K. 1999. Factors associates with being a bovine-virus diarrhea seropositive dairy herd in the MØre and Romsdal County of Norway. Preventive Veterinary Medicin 40. ss. $165-177$. Wendroth, O., Reuter, H.I. \& Kersebaum, K.C. 2003. Predicting yield of barley across a landscape: a state-space modeling approachs. Journal of Hydrology 272. ss. 250-263.

White, P., Böhm, M., Marion, G. \& Hutchings, M. 2008. Control of bovine tuberculosis in British livestock. Trends in Microbiology 16,( 9) ss. 420-427.

Zalom, F. 1993. Reorganizing to facilitate the development and use of integrated pest management 46. Agriculture, Ecosystems and Environment 46 ss. 245-256.

Öhlmer, B., Göransson, B. \& Lunneryd, D. 2000. Business management - with applications to farms and other businesses. Uppsala: Sveriges lantbruksuniversitet Institutionen för ekonomi. 248 s. 